\title{
RELATIONSHIP BETWEEN THE DETERMINANTS OF CAPITAL STRUCTURE AND DEBT RATIO: EVIDENCE FROM LISTED MANUFACTURING COMPANIES IN SRI LANKA
}

\author{
Athambawa Haleem \\ Department of Accountancy and Finance, \\ Faculty of Management and Commerce, \\ South Eastern University of Sri Lanka, Sri Lanka
}

\begin{abstract}
It is mostly due to the factors that decide the overall capital structure of the company. A greater capital structure helps the company realize both sustainable long-term Growth and long-above average results. The objective of this study is to find out the relation between capital structure and debt ratio of manufacturing companies listed in the Colombo Stock Exchange. Thus, the study was considered with panel data for the period of 2011-2015 of the twenty six companies. Correlation, and multiple regression analysis of statistical tools were used to analyze and to test the hypothesis of the study. In this analysis, the dependent variable is the debt ratio of the firms and the Capital structure determinants, which are measured by Profitability, Tangibility, firm size, Growth, and non-debt tax shield. The results showed that Profitability, Growth, Firm Size, and Non-Debt Tax shield have significant impact on debt ratio except Tangibility. Further, it finding showed that the firm size mostly consistent with trade-off theory and profitability and growth consistent with packing order theory and prove past empirical findings also.
\end{abstract}

Keywords: Capital Structure, Debt Ratio

\section{Introduction}

Capital is a requirement for developing companies. The capital may be collected by either borrowing money or raising money from bonds. When it comes to funding, whether by Debt or equity, it is important to worry about whether the businesses would be able to do so. What is the right way to do it? In this case, does it make sense to use all Debt or all equity? Let's say that the ideal clarification requires any debt and equity integration, so what will be the perfect blend? The capital structure of an organization is a mix of Debt and equity (Sithy Safeena, 2014). The entity should use the best capital structure that results in the lowest capital cost.

When assessing if a company is a solvent, a debt ratio can be used, which estimates a firm's net obligations as a percentage of its total assets. If the debt ratio is higher, the more leveraged a company is, and it implies that there is a greater financial risk. Using equity is a major strategy that firms use to expand the company and use Debt in order to boost their growth.

For the retention of the industry, development, and performance of the firm, capital structure is more important. Everyone has started to pay heed to the red flags associated with Debt leveraging (Voulgaris, Asteriou, \& Agiomirgianakis, 2004). One of the most critical policy decisions for companies is their capital structure, and it has been thoroughly studied. Capital structure decisions are particularly critical for all firms, as well as manufacturing companies (Tharmalingam \& Banda, 2016). Capital 
structure decisions are crucial to the sustainability of the corporate model of operation. Selecting Debt and equity instruments in a fair manner is complicated because there are varying risks and benefits to the securities. When it comes to selecting a method of security, the wrong decisions will result in financial difficulty and bankruptcy. These influences, which impact capital structure, have been studied extensively, and their findings are seen in many countries, including the UK, Greece, Qatar, the Arabian Peninsula, Ghana, Australia, Pakistan, Indonesia, Brazil, India, and more. To put it another way, capital structure determinants have not yet been studied in detail in any of their variations. Those do not play much of a role in Sri Lankan context, owing to their lack of use of panel data processing. With this report, the research void on this topic can now be filled. For this cause, there are almost no studies linked to capital structure determinants in listed Sri Lankan manufacturing firms. Here, the research's key objective is to find out which factors decide the debt ratios of listed manufacturing companies.

Financial researchers from all over the world are continuing to undertake studies on the capital structure, and so it remains challenging to determine acceptable proportions of debt capital to equity capital. Investigations on the most significant indicators of capital structure continue, but as of yet, there are no completed studies to examine the full spectrum of capital structure effects in Sri Lanka. Finally, the above information is in accordance with data from a different area. There are, however, a minimum number of studies that look into the characteristics of the manufacturing sector's capital structure in Sri Lanka. It should take into consideration profitability, Tangibility, firm scale, Growth, and nondebt tax shield when formulating capital structure strategy. Hence, the researcher concentrated on the capital structure of listed manufacturing firms in Sri Lanka to assess their causes. Also, the researcher is studying the effect of contributing factor of capital structure on the debt ratio of listed manufacturing firms.

\section{Literature}

\section{The Concept of Capital Structure}

Modigliani and Miller (1958) carried out a groundbreaking examination on the capital structure theory and the researchers suggested that the capital structure of the entity has no impact to determine the value of the company in the complete market is the MM theory. The scholars have been widely investigated the issue of the entity's capital structure. Robichek (1966) and some others proposed a tradeoff theory. The entities must consider the tax avoidance impact and the bankruptcy cost of liabilities when they decide the capital structure. The agency cost was suggested by (Jesen \& Meckling, 1976). The Theory differentiates between two company's contradictions of interest. The first one is the equity agency happened by contradicting of interest betwixt shareholders and executives. The second one is the cost of debt agency occurred by disagreeing of interest between shareholders and creditors.

\section{Capital Structure Theories}

There have been some critical theories regarding capital structure choice that has already been developed firm's leverage option can be seen from the various speculations: Modigliani-Miller theory, Signaling Theory, the Market control hypothesis. These theories are discussed one by one as follows:

\section{Modigliani and Miler Theory}

This was started by Modigliani and Miller in 1958. They predicted that the market would be more effective when there are no taxes. They depicted that the organization's value doesn't base on the debts taken by the entity. This model based on two keys, as depicted by Modigliani and Miller (1958). They are arbitrage and borrowing on personal accounts.

\section{Signaling Theory}

The signaling Theory radiates from data imbalances between firm administration and investors. In the event that directors accept that their organizations are underestimated, they will issue Debt first and afterward issue 
equity if all else fails. Alternately, if the executives accept that their entity is exaggerated, they will issue equity first. The signaling Theory was first-authored by Ross (1977), who sets that if managers have inside information, their decision of capital structure will flag data to the market.

\section{The Market Timing Theory}

In accordance with the equity capital structure principle, the company issues shares when the markets are over-valued and repurchases them when they are cheap. This continuous change in the costs of supplies of firms impacts the capital structure of the entity. The equity market time theory has two renditions of capital structure dynamics. The practical issue is the way to gauge the indicator of capital structure, which elements have solid impacts on the monetary leverage of firms to contrast and utilizing the Tradeoff theory and Pecking-order. In this manner, can assume the effects of these indicators on capital structure in the case of Sri Lankan manufacturing organizations.

\section{Review on the Factors of Capital Structure}

The financial structure of organizations in developing economies is affected by the same capital structure as Giannetti (2003) observed. Giannetti of this study noted that the variables that affect the total capital structure of a firm include company size, the non-debt tax rate, and the collateral asset valuation of the corporation. These variables are influential when assessing an organization's leverage: the median industrial leverage, market capitalization to book ratio, the capacity of debt guarantee, profitability, payment of dividend, asset logarithm, and the fixed impact of the entity or management (Frank \& Goyal, 2003). A business analysis published in 2008 indicates that there is a strong correlation between profitability, Growth, and various other organization-level variables in relation to capital structure. From the viewpoint of the industry, the competition between commodity markets and the financial leverage in different industries are mutually associated. Market value to book value (MTB), profitability (Sithy Safeena, 2015), size, collateral value, the dummy variable of the dividend payout, and the fixed effect variable of the time and region are the primary attributes of a bank's company-level variables, according to (Gropp \& Heider, 2009).

Researchers (e.g.: Korajczyk and Levy, 2003) analyzed the macroeconomic environment using the entity's total performance, short-term interest rates, maturity spreads, and credit spreads. With respect to sample size, they suggested that participants were willing to invest no more than $90 \%$ of their revenue. The different countries' legal structures greatly affect the capital structure of the company (Bancel \& Mittoo, 2004). Jong et al. (2008) show that bond market structure, stock market structure, capital accumulation rate, and GDP growth all have an effect on the structure of the capital, which functions in both direct and indirect ways.

Zhang et al., (2000) contemplated the effect of the capital structure of listed organizations by choosing 943 listed companies in Shenzhen and Shanghai. They uncovered that the development, size, and debt ratio are correlated positively. Also, they have uncovered that the retained earnings, corporate resource profitability, and debt ratio are adversely related. As indicated by Dongwei and Haijian (2009), the organization-level factors comprise scale (LNSALES), debt guarantee capability (TANGIBLE), non-debt tax shield (NDTS), age (AGE), profitability (ROA), and profit fluctuation (STDROA).

Gamini (2008) examined the influencing factors of capital structure of corporate capital structure in Sri Lanka. The study consisted of the cross-sectional regression analysis of the determinants of the organization's obligation to total assets ratios of a sample of 74 Sri Lankan manufacturing organizations for the time frame 1998-2002. The study included a variety of variables in regression equations, including profitability, market risk, corporate size, growth rate, and age, which serve as potential determinants of debt ratios recorded in the empirical 
literature. From the study's findings, it appears that the indicator of profitability was to be found in the ratio of debt obligations of Sri Lankan companies. The analysis validates the argument that more profitable businesses keep their investment programs in storage using retained profits and have a lower debt to equity ratio, as compared to inefficient corporations. While corporate size and growth rate were not precisely related to firms' debt ratios, specific relationships between corporate size and growth rate and debt ratios exist. As theorized, the coefficient of asset structure (i.e., the negative effect of asset structure on revenue) is higher than the coefficient of market risk (i.e., the positive influence of business risk on revenue).

PhamThi Hau et al. (2014) led an investigation on "The determinants of capital structure: Evidence from Vietnam listed companies." The study aimed to study and investigate definitions, theories, and models of determinants that sway an entity's capital structure. Mainly express on the trait of Vietnam's competitive market. Data on the listed companies in Vietnam Stock Exchange is utilized by the researchers over the period of 2009-2013. Using this analysis, the empirical and subjective aspects of the relationship between leverage and different independent variables, which include firm size, profitability, Tangibility, state proprietor, and industry, are examined. Using Microsoft Excel and STATA 11, regression models were performed. In their examination, they have discovered that profitability, size, and state have critically identified with leverage with a $\mathrm{p}$-value under 0.05. Alternately, tangible assets, just as industry faker variables, aren't firmly clarifying for changing the monetary leverage ratio. There are three variables as Size, Profit, and State, which impact the capital structure of listed firms in Vietnam in the given period 2009-2013.

Irfan Ali (2011) examined on the "Determinants of capital structure: Empirical evidence from Pakistan" with the objective of analyzing the capital structure of an attempt to see what factors impact the capital structure of the company. The researcher used capital structures of non-financial firms listed on Karachi Stock Exchange (Pakistan) for the period of 2003 to 2008. The research reveals that it was statistically significant for profitability, size, Tangibility, Growth, dividend, and inflation. There is a negative relationship between profitability and leverage. In between Growth and long-term Debt and dividend and Debt of entities, there is a positive relationship. It affirms the presence of pecking order theory in determining the financing behavior of Pakistani entities. In between Tangibility and leverage and size and leverage support, there is a strong positive association. It assists the theoretical estimations of trade-off Theory. There is a positive relationship between expected future inflation and current burrowing. It supports market timing theory. The findings of the research reveal that there is a significant change in the financing behavior of entities via industries. The combination of equity and Debt is known as Capital Structure. The nature of Capital Structure is dynamic. It varies under different conditions; it refers to capital structure determinants (CSD) which consists; firm size, asset structure, profitability, liquidity, financial flexibility, growth etc. Determinants are identified as determinants of firm-specific capital structure; many researchers have concluded that Capital Structure determinants are varied (Antwi, Mills \& Zhao ,2012; Sithy Safeena 2015). In determining the growth of all businesses, capital structure is always a significant factor. A pivotal function of capital structure is the generation of income and the enhancement of the country's productive potential. Therefore, it's difficult for them to ignore the value of the capital structure in today's highly competitive environment. Furthermore, numerous systematic studies have analyzed how various variables affect capital structure.

\section{Methodology}

\section{Conceptual Model}

To depict the relationship between determinants of capital structure and Debt ratio of the companies, the following conceptual framework is formulated. 


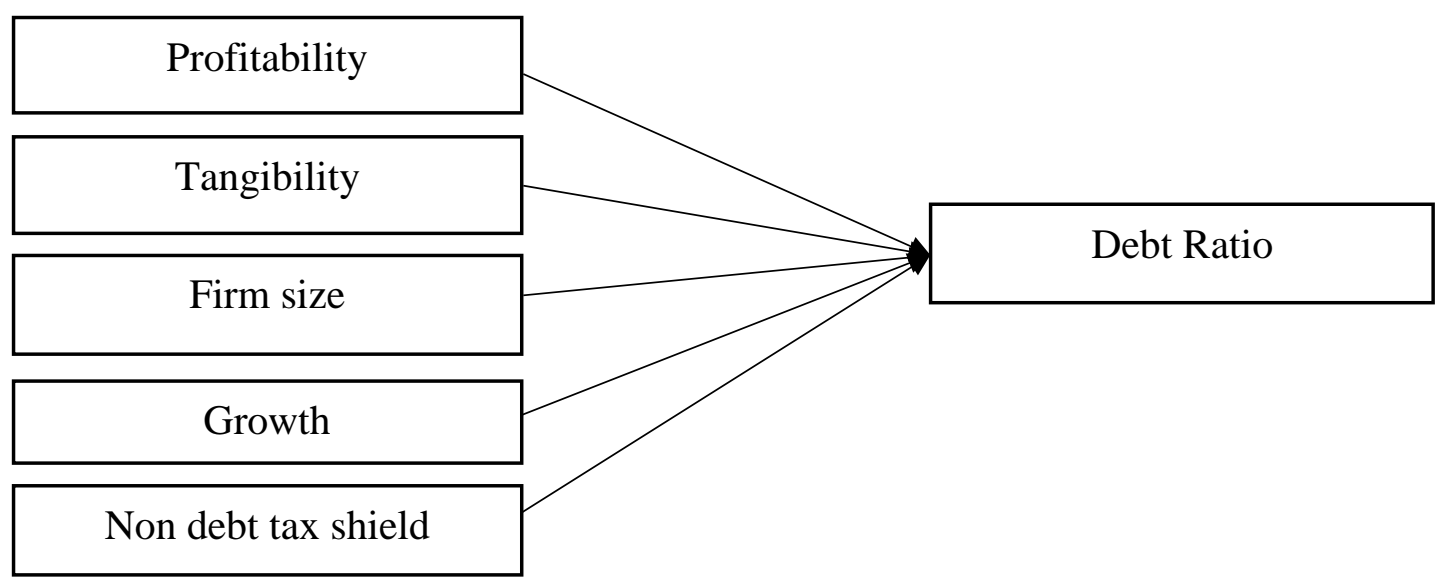

Figure 1: Conceptual Model

\section{Description of the Variables}

The investigation used the debt ratio (DR) as the dependent variable. There are a number of factors, according to the literature which is likely to affect an entity's decision on capital structure. In order to explain the variations in the leverage, a set of explanatory variables have been used. The entities identified in the literature as having an impact on the company's decisions are either instrumental or value-creating leverage. This research investigated the impact of five firm-level characteristics (Explanatory variables) Profitability, Tangibility, Size, Growth, and non-debt tax shield on the capital structure decisions.

Profitability is quite possibly the most tried organizational qualities in observational exploration to the firm's decision of capital structure. Titman and Wessels (1998), using income statements, showed financial performance compared to gross assets and total net benefit ratios. Wiwattanakantang (1999) used the return on assets, and Rajan and Zingales,(1995), Ooi,(1999) Ozkan, (2001), and Gaud et al.,(2005) were used return on total assets as indicators of profitability in measuring profitability ratio. So in this study, the researcher used the proportion of earnings before interest and tax to total assets as an intermediary for profitability (PROF).

The tangible assets of an entity can be regarded as the agents of genuine assurances to its lenders. Tangibility (TANG) is as the proportion of tangible resources in addition to inventories to total assets utilizing book values in steady with the measure utilized by (Chen, 2003; Gaud et al., 2005). In this investigation, the researcher utilized the proportion of total gross fixed assets for total assets as an intermediary for Tangibility (TANG).

Firm size has been perhaps the most widely recognized factor utilized in clarifying a company's degree of Debt. Several pointers like logarithm of net sales were used in literature (Titman \& Wessels, 1988; Rajan \& Zingales, 1995; Graham, 2000; Ozkan, 2001; Gaud et al., 2005). Padron et al., (2005) used the natural logarithm of total assets. Chung (1993) used the average value of total assets in the previous studies. Total assets at book value (Scott and Martin, 1975) and the market value of the entity Graham, (2000) were utilized in previous studies to quantify size. In this investigation, the researcher utilized the natural logarithm of sales in genuine terms as an intermediary for size.

Growth is identified with new speculations and the market valuation of the organizations. Padron et al., (2005) used the ratio of the market value of the company over the total liabilities in estimating the influence of growth. Cortez and Susanto, (2012), Sayilgan et al., (2006) and Titman and Wessels, (1988) used the yearly growth in 
total assets or total fixed assets of the entity. The proportion of investment expenditure over total assets was used by (Titman and Wessels, 1988; Gaud et al., 2005; Rajan and Zingales, 1995; and Myers, 1977) used the proportion of the market value of the assets over the accounting value of the assets in estimating the impacts of growth. This investigation estimated growth as a percentage increase in total assets (GROW).

The entities want to exploit the tax deductibility of interest in reducing the tax bill. If the payer does not have any such taxdeductible expenditure, it serves only as a tax shield. Therefore, a negative association is existing in between non-debt tax shield and leverage. So, in this study, the researcher used the ratio of earnings after interest and tax to total assets as an intermediary for nondebt tax shield(NDTS).

\section{Model of Study}

The research examined the determining factor of the capital structure of manufacturing entities in Sri Lanka. This study is conducted using a linear multiple regression model used by Ram Kumar, Kalkani et al. (1998), which has been modified to suit the explanatory data limitations. The study used a measure of capital structure based on book value. It is the debt ratio (DR). The study focused the significant variables such as: Tangibility (TANG), profitability (PROF), firm size (FSIZE), and Growth (GROW), Non-Debt Tax Shield (NDTS) as independent variables. Multiple regression techniques have been employed to quantify the influences of the capital structure. Here is how the models as follows

$\mathrm{DR}=\mathrm{a}+\beta 1 \mathrm{PROF}+\beta 2 \mathrm{TANG}+\beta 3$ FSIZE $+\beta 4$ GROW $+\beta 5$ NDTS $+\hat{I}$

(Where $\mathrm{a}$ is constant, $\beta 1, \beta 2, \beta 3, \beta 4, \beta 5$ are coefficients of variables $\hat{I}$, is the residual term)

\section{Development of Hypothesis}

For the purpose of identifying the factors determining the capital structure and analyzing how those factors affecting the capital structure decision of manufacturing companies listed in Sri Lanka. The following hypothesis is going to be tested.

H1: There is a significant impact of profitability on the debt ratio.

$\mathrm{H} 2$ : There is a significant impact of Tangibility on the debt ratio.

H3: There is a significant impact of Firm size on the debt ratio.

H4: There is a significant impact of Growth on the debt ratio.

H5: There is a significant impact of nondebt tax shield on the debt ratio.

\section{Data Collection}

This study relies on a survey of companies from 2010/11-2014/15 using financial records. Companies selected in this study have included extensive income and financial information in the Colombo Stock Exchange (CSE) database.

Since this research supposes to test the factors determining the capital structure of listed companies of Sri Lanka. The population of this study is the listed manufacturing companies in the Colombo Stock Exchange by covering five years period of time (2010/11-2014/15). There are 294 companies listed in the CSE in 2016.

The study is based on the companies are listed on the manufacturing sector in Colombo Stock Exchange. Presently 40 manufacturing firms are listed in Colombo Stock Exchange. The periodical sampling period began in 2010/11, and specimens were gathered over the five-year span as the required firm-specific data became available. Hence, 14 firms were excluded because their financial period didn't satisfy the study period ranging 2010/11-2014/15 and unavailability of data. Finally, 26 firms were selected as sample size. So, there were 130 firm-years for panel data analysis.

\section{Findings}

\section{Descriptive Statistics}

The statistics in the analysis open up the possibility of the most insightful 
conclusions. Table 1 presents the descriptive statistics of the data, containing maximum, minimum, mean values, and standard deviation.

Table 1: Descriptive Statistics

\begin{tabular}{|l|l|l|l|l|l|}
\hline & $\mathrm{N}$ & Minimum & Maximum & Mean & $\begin{array}{l}\text { Std. } \\
\text { Deviation }\end{array}$ \\
\hline Profitability & 130 & -.28 & .36 & .0849 & .10103 \\
\hline Tangibility & 130 & .02 & .74 & .3130 & .16355 \\
\hline Firm size & 130 & 7.62 & 10.22 & 9.0381 & .58881 \\
\hline Growth & 130 & -.41 & .88 & .1046 & .18523 \\
\hline NDTS & 130 & -.64 & .76 & .0937 & .19832 \\
\hline TDR & 130 & .06 & 1.81 & .4267 & .20819 \\
\hline $\begin{array}{l}\text { Valid N (list } \\
\text { wise) }\end{array}$ & 130 & & & & \\
\hline
\end{tabular}

The above table 1 indicates that the average rate of profitability is $8.49 \%$ during the period. The tangibility mean is $31.3 \%$, the maximum is $74 \%$, while the minimum is $2 \%$. The average size of the firm is $9.03 \%$ and the maximum is $10.22 \%$, while the minimum is $7.62 \%$. And standard deviation also high for the firm size during this period. The mean for Growth is $10.46 \%$, and maximum Growth is $88 \%$, while the minimum is $-41 \%$. The average rate of non-debt tax shield (NDTS) is $9.3 \%$, and the maximum non-debt tax shield (NDTS) is $76 \%$, while the minimum non-debt tax shield (NDTS) is $-64 \%$. The average capital structures (DR) are about $42.67 \%$ which indicates manufacturing sector companies finance their asset of $42.67 \%$ by Debt during the study period.

\section{Correlation Analysis}

The Pearson's Moment Correlation was used to define the relationship between various determinants of capital structure (profitability, Tangibility, firm size, Growth, and non-debt tax shield) and leverage (Debt), and it is presented in table 2 .

Table 2: Correlation Analysis

\begin{tabular}{|c|c|c|c|c|c|c|c|}
\hline & & $\begin{array}{l}\text { Profitabili } \\
\text { ty }\end{array}$ & $\begin{array}{l}\text { Tangibilit } \\
\mathrm{y}\end{array}$ & Firm size & $\begin{array}{l}\text { Growt } \\
\mathrm{h}\end{array}$ & $\begin{array}{l}\text { NDT } \\
\text { S }\end{array}$ & DR \\
\hline \multirow[t]{3}{*}{$\begin{array}{l}\text { Profitabili } \\
\text { ty }\end{array}$} & $\begin{array}{l}\text { Pearson } \\
\text { Correlati } \\
\text { on }\end{array}$ & & & & & & \\
\hline & $\begin{array}{l}\text { Sig. (2- } \\
\text { tailed) }\end{array}$ & & & & & & \\
\hline & $\mathrm{N}$ & & & & & & \\
\hline \multirow[t]{3}{*}{$\begin{array}{l}\text { Tangibilit } \\
\mathrm{y}\end{array}$} & $\begin{array}{l}\text { Pearson } \\
\text { Correlati } \\
\text { on }\end{array}$ & -.067 & & & & & \\
\hline & $\begin{array}{l}\text { Sig. (2- } \\
\text { tailed) }\end{array}$ & .451 & & & & & \\
\hline & $\mathrm{N}$ & 130 & 130 & & & & \\
\hline Firm size & $\begin{array}{l}\text { Pearson } \\
\text { Correlati }\end{array}$ & $.346^{* *}$ & .091 & & & & \\
\hline
\end{tabular}




\begin{tabular}{|c|c|c|c|c|c|c|c|}
\hline & on & & & & & & \\
\hline & $\begin{array}{l}\text { Sig. (2- } \\
\text { tailed) }\end{array}$ & .000 & .304 & & & & \\
\hline & $\mathrm{N}$ & 130 & 130 & 130 & & & \\
\hline \multirow[t]{3}{*}{ Growth } & $\begin{array}{l}\text { Pearson } \\
\text { Correlati } \\
\text { on }\end{array}$ & $.174^{*}$ & -.064 & .013 & & & \\
\hline & $\begin{array}{l}\text { Sig. (2- } \\
\text { tailed) }\end{array}$ & .047 & .467 & .886 & & & \\
\hline & $\mathrm{N}$ & 130 & 130 & 130 & 130 & & \\
\hline \multirow[t]{3}{*}{ NDTS } & $\begin{array}{l}\text { Pearson } \\
\text { Correlati } \\
\text { on }\end{array}$ & $.766 * *$ & -.059 & $\begin{array}{c}.264^{*} \\
*\end{array}$ & $.197 *$ & & \\
\hline & $\begin{array}{l}\text { Sig. (2- } \\
\text { tailed) }\end{array}$ & .000 & .502 & .002 & .025 & & \\
\hline & $\mathrm{N}$ & 130 & 130 & 130 & 130 & 130 & \\
\hline \multirow[t]{3}{*}{ DR } & $\begin{array}{l}\text { Pearson } \\
\text { Correlati } \\
\text { on }\end{array}$ & -.101 & .019 & $\begin{array}{c}.300^{*} \\
*\end{array}$ & .130 & $\begin{array}{c}- \\
.204 \\
*\end{array}$ & \\
\hline & $\begin{array}{l}\text { Sig. (2- } \\
\text { tailed) }\end{array}$ & .253 & .834 & .001 & .141 & .020 & \\
\hline & $\mathrm{N}$ & 130 & 130 & 130 & 130 & 130 & $\begin{array}{c}13 \\
0\end{array}$ \\
\hline
\end{tabular}

*. Correlation is significant at the 0.05 level (2-tailed).

**. Correlation is significant at the 0.01 level (2-tailed)

The Pearson correlation of coefficient between debt ratio (DR) and profitability (PROF) is -0.101 . This negative coefficient illustrates; there is a moderate negative correlation between the Debt and profitability of the manufacturing firms. This correlation is insignificant because the significant value of PROF ( $\mathrm{P}$-value $=0.253$ ) is greater than the significant value $(0.05)$.

The tangibility of the firm and Debt has a weak positive correlation (0.019). And also, tangibility is insignificant with Debt because the significant value $(\mathrm{P}-\mathrm{value}=0.834)$ greater than the tested value (0.05). Therefore, at a $5 \%$ significance level statistically concludes that the correlation between Tangibility and Debt is positively insignificant.

The correlation of coefficient between firm size (FSZE) and Debt is 0.300; this is a moderate positive relationship. This correlation is significant because the significant value of PROF $(\mathrm{P}$-value $=0.001)$ is lesser than the significant value (0.05). This suggests that the correlation between the firm size and Debt is positively significant in the manufacturing firms in Sri Lanka

Growth of the firm and debt position is in correlation (0.130). And also, Growth is not significant with the debt ratio because of the significant value $(\mathrm{P}$-value $=0.141)$ higher than the tested value $(0.05)$. Therefore, at a $5 \%$ significant level statistically concludes that the correlation between Growth and Debt is insignificant.

Non-debt tax shield of the firm and negative debt correlation (- 0.204). And also, the nondebt tax shield is having a significant relationship with Debt because the significant value $(\mathrm{P}$-value $=0.020)$ lower than the tested value $(0.05)$. Therefore, at a $5 \%$ significant level statistically concludes that the correlation between non-debt tax shield and debt ratio is insignificant. 


\begin{tabular}{|l|l|l|l|l|l|}
\hline Model & $\mathrm{R}$ & $\begin{array}{l}\mathrm{R} \\
\text { Square }\end{array}$ & $\begin{array}{l}\text { Adjusted } \\
\text { Square }\end{array}$ & $\begin{array}{l}\text { Std. Error of the } \\
\text { Estimate }\end{array}$ \\
\hline 1 & $.531 \mathrm{a}$ & .282 & .253 & .17994 \\
\hline
\end{tabular}

a. Predictors: (Constant), NDTS, Tangibility, Growth, Firm size, Profitability

b. Dependent Variable: TDR

As can be seen from the multiple regression results, $28.2 \%$ of the debt variability can be explained by a combination of the five explanatory variables together. $71.8 \%$ of the difference in Debt is due to other factors.

Table 4: ANOVAa

\begin{tabular}{|l|l|l|l|l|l|l|}
\hline \multicolumn{2}{|c|}{ Model } & $\begin{array}{l}\text { Sum of } \\
\text { Squares }\end{array}$ & df & $\begin{array}{l}\text { Mean } \\
\text { Square }\end{array}$ & F & Sig. \\
\hline \multirow{2}{*}{1} & Regression & 1.576 & 5 & .315 & 9.737 & $.000 \mathrm{~b}$ \\
\cline { 2 - 7 } & Residual & 4.015 & 124 & .032 & & \\
\cline { 2 - 7 } & Total & 5.591 & 129 & & & \\
\hline
\end{tabular}

a. Dependent Variable: TDR

b. Predictors: (Constant), NDTS, Tangibility, Growth, Firm size, Profitability

The $\mathrm{F}$ value is 9.37 , which is important at the $\mathrm{p}$ conclusion that the variables (variable) justify $=0.05$ percentile, which supports the $16.7 \%$ of the difference in Debt.

Table 5: Coefficientsa

\begin{tabular}{|c|c|c|c|c|c|c|}
\hline \multicolumn{2}{|r|}{ Model } & \multicolumn{2}{|c|}{$\begin{array}{l}\text { Unstandardized } \\
\text { Coefficients }\end{array}$} & \multirow{2}{*}{$\begin{array}{c}\begin{array}{c}\text { Standardize } \\
\mathrm{d} \\
\text { Coefficients }\end{array} \\
\text { Beta }\end{array}$} & \multirow[t]{2}{*}{$\mathrm{t}$} & \multirow[t]{2}{*}{ Sig. } \\
\hline & & B & $\begin{array}{c}\text { Std. } \\
\text { Erro } \\
r\end{array}$ & & & \\
\hline \multirow[t]{6}{*}{1} & (Constant) & -.556 & .261 & & $\begin{array}{c}- \\
2.12 \\
6\end{array}$ & $\begin{array}{c}.03 \\
5\end{array}$ \\
\hline & $\begin{array}{c}\text { Profitabilit } \\
y\end{array}$ & $\begin{array}{c}2.25 \\
3\end{array}$ & .652 & 1.093 & $\begin{array}{c}3.45 \\
6\end{array}$ & $\begin{array}{c}.00 \\
1\end{array}$ \\
\hline & Tangibility & -.003 & .098 & -.003 & -.035 & $\begin{array}{c}.97 \\
2\end{array}$ \\
\hline & Firm size & .100 & .030 & .283 & $\begin{array}{c}3.30 \\
7\end{array}$ & $\begin{array}{c}.00 \\
1\end{array}$ \\
\hline & Growth & .232 & .088 & .206 & $\begin{array}{c}2.64 \\
5\end{array}$ & $\begin{array}{c}.00 \\
9\end{array}$ \\
\hline & NDTS & $\begin{array}{c}- \\
1.44 \\
4\end{array}$ & .324 & -1.375 & $\begin{array}{c} \\
4.45 \\
9\end{array}$ & $\begin{array}{c}.00 \\
0\end{array}$ \\
\hline
\end{tabular}

Based on the above result researcher developed the following regression equation.

$\mathrm{DR}=-0.556+2.253 \mathrm{PROF}+0.100 \mathrm{FSIZE}+$ 0.232 GROW-1.444NDTS
This multiple linear regression equation shows that $B$ equals to, $-0.556,2.253$, $0.003,0.100,0.232$ and -1.444 give an indication of the relative importance of the predictor variables in uniquely accounting for variance in the dependent variables, 
which simply indicates that there is a significant impact of Profitability, firm size, Growth and non-debt tax shield on debt ratio since the significant values are less than 0.05. Therefore, the findings revealed that Profitability, firm size, and Growth have a significant positive impact on the debt ratio in the manufacturing sector in the CSE in Sri Lanka. And also, Tangibility has not a significant relationship with the debt ratio of a manufacturing firm in Sri Lanka during the period of 2010/20111-2014/2015. Additionally, the degree of profitability is a more significant variable than profitability compared to other variables that indicate which variant of the Debt is more useful for financial accounting.

Hypothesis $\mathrm{H} 1$ is tested whether there is a significant influence of profitability on debt ratio or not. There is a positive relationship between the debt ratio and profitability. The $\mathrm{t}$-statistic and significant values are 3.456, 0.001 respectively. It reflects that the t-value is significant at $5 \%$ significant level because the significant value of profitability 0.001 is lesser than the tested alpha value (0.05). Hence, the null hypothesis is rejected, and the alternative hypothesis is accepted. Therefore, at 5\% significant level, statistically conclude that there is a significant impact of profitability on the debt ratio of a manufacturing firm in Sri Lanka.

Hypothesis $\mathrm{H} 2$ is tested whether there is a significant influence of Tangibility on debt ratio or not. Tangibility has a weak negative association with debt ratio because the beta coefficient of Tangibility is -0.003 . The $t-$ statistic and significant values are -0.035 , 0.972 respectively. It reflects that the t-value is insignificant at a 5\% significant level because the significant value of 0.972 is greater than the tested alpha value (0.05). Hence, $\mathrm{H} 2$ is rejected. Therefore, at a $5 \%$ significant level, statistically conclude that there is no significant impact of Tangibility on the debt ratio of manufacturing firms in Sri Lanka.

Hypothesis $\mathrm{H} 3$ is tested whether there is a significant influence of firm size on debt ratio or not. There is a positive correlation between the debt ratio and firm size. The tstatistic and significant values are 3.307, 0.001 respectively. It reflects that the t-value is significant at a 5\% significant level because the significant value of 0.001 is lesser than the tested alpha value (0.05). Hence, H3 is accepted. Therefore, at a 5\% significant level, statistically conclude that there is a significant impact of Firm size on the debt ratio of manufacturing firms in Sri Lanka.

Hypothesis $\mathrm{H} 4$ is tested whether there is a significant influence of Growth on debt ratio or not. There is a moderate positive correlation between the debt ratio and Growth. The t-statistic and significant values are $2.645,0.009$ respectively. It reflects that the t-value is significant at $5 \%$ significant level because the significant value of 0.009 is lesser than the tested alpha value (0.05). Hence, $\mathrm{H} 4$ is accepted. Therefore, at 5\% significant level, statistically conclude that there is a significant impact of Growth on the Debt of manufacturing firms in Sri Lanka.

Hypothesis $\mathrm{H} 5$ is tested whether there is a significant influence of non-debt tax shield on debt ratio or not. There is a negative correlation between the debt ratio and Growth. The t-statistic and significant values are $4.459,0.000$ respectively. It reflects that the t-value is significant at $5 \%$ significant level because the significant value of 0.000 is lesser than the tested alpha value (0.05). Hence, H5 is accepted. Therefore, at 5\% significant level, statistically conclude that there is a significant impact of Growth on the Debt of manufacturing firms in Sri Lanka.

\section{Conclusion and Recommendations}

\section{Conclusion}

This current study evaluated the association between capital structure determinants and leverage level of manufacturing entities on the Colombo Stock Exchange during a fiveyear period (2010/11-2014/15). This study employed with debt ratios of debt ratios (a measure of leverage) as the dependent variable. The basic purpose of this study was to test the postulated assumptions and to provide evidence with respect to the 
influence of firm capital structure determinants and leverage level by examining factors such as profitability, Tangibility, firm size, Growth, and non-debt tax shield.

Pearson correlation coefficient and multiple regression parameters were computed to analyze the impact of capital structure determinants on the leverage level. In the regression model, TDR is used as a dependent variable, while Profitability, Tangibility, firm size, and growth variables are used as independent variables in the model.

This research into the decision-making process of capital structure contributes to a deeper understanding of the economic conditions in Sri Lanka. This study looks at financial capital structure decisions from $2010 / 11$ to $2014 / 15$ and how the relationship depends on leverage. The results of regression find that firm size and non-debt tax shield were confirmed to be significant determinants of Debt. Profitability, Tangibility, and Growth were confirmed not to have a significant impact in the Debt of manufacturing firms.

\section{Recommendation}

This section acts as a forum for more researchers to source their ideas. Further studies may include the following. Such variables may also be explored. Extending the existing study areas may be to explore the particular factors that affect capital structure on non-listed firms. If various proxies had been used to calculate the factors, the findings of the study would have been somewhat different. Additional analysis is also recommended in order to integrate multiple proxies. Such research into longterm firm finance actions can offer further insight into financial decisions.

\section{References}

Antwi, S., Mills, E. F., \& Zhao, X. (2012). Capital Structure and Firm Value: Empirical Evidence from Ghana, International Journal of Business and Social Science, 3(22), 103-111
Bancel, F. \& Mittoo, U.R. (2004). CrossCountry Determinants of Capital Structure Choice: A Survey of European Firms, Financial Management, 33, 103-132.

Chen, J. (2004). Determinants of the capital structure of Chinese-listed corporations, Journal of Business Research, Vol.57, No.2, pp 1341-1351.

Cortez, M.A. \& Susanto, S. (2012). The Determinants of Corporate Capital Structure: Evidence from Japanese Manufacturing Companies, Journal of International Business Research, 11, pp. 122-134.

Frank, M.Z. \& Goyal, V.K. (2003). Testing the Pecking Order Theory of Capital Structure, Journal of Financial Economics, 67, 217-248. https://doi.org/10.1016/S0304405X(02)00252-0

Gamini, L.P.S (2008). Determinants of Capital Structure - A Case in Sri Lanka. Journal of Humanities and Social Sciences, Vol-4.

Gaud, P., Jani, E., Hoesli, M. \& Bender, A. (2005). The capital structure of Swiss companies: an empirical analysis using dynamic panel data, European Financial Management, 11(1), 51-69.

Giannetti, M. (2003). Do Better Institutions Mitigate Agency Problems? Evidence from Corporate Finance Choices, Journal of Financial \& Quantitative Analysis, 38, 185-212. https://doi.org/10.2307/4126769

Graham, J.R. (2000). How big are the Tax Benefits of Debt?, Journal of Finance 55, 1901-1941.

Gropp, R. \& Heider, F. (2009). The Determinants of Bank Capital Structure, Social Science Electronic Publishing, 14, 587-622.

Irfan Ali (2011). Determinants of capital structure: Empirical evidence from Pakistan. Master thesis, University of Twente.

Jensen, Michael C. \& Meckling, William H., (1976). Theory of the firm: Managerial 
behavior, agency costs and ownership structure, Journal of Financial Economics, Elsevier, vol. 3(4), pages 305-360, October.

Korajczyk, R.A. \& Levy, A. (2003). Capital Structure Choice: Macroeconomic Conditions and Financial Constraints, Journal of Financial Economics, 68, 75-109.

https://doi.org/10.1016/S0304405X(02)00249-0

Modigliani \& Miller (1958). American Economic Association the Cost of Capital, Corporation Finance and the Theory of Investment, The American Economic Review, 48, 261-297.

OOI, J.T.L. (1999). The debt maturity structure of UK property Companies, Journal of Property Research, 16(4), pp. 293-307.

Ozkan, A. (2001). Determinants of Capital Structure and Adjustment to Long Run Target: Evidence from UK Company Panel Data, Journal of Business Finance \& Accounting, 28, 175-198.

Padron, Y.G., Apolinaro, R.M.C., Santana, O.M., Conception, M., Martel, V., \& Sales, L.J. (2005). Determinant factors of leverage: An empirical analysis of Spanish corporations, Journal of Risk Finance, 6(1), 60-68

Pham Thi Hau, Do Thi Thu Trang, Nguyen Thi Bitch Ngoc,Le Hong Thu \& Vy Thi Tuyet Trinh(2014). The determinants of capital structure: Evidence from Vietnam listed companies. Bachelor of Corporate Finance Thesis, FPT school of business.

Rajan, R.G. \& Zinggales, L. (1995). What do we know about capital structure? Some evidence from international data, Journal of Financial Economic, 50(5), 1421-1460.

Robichek, A.A. \& Myers, S.C. (1966). Problems in the Theory of Optimal Capital Structure, Journal of Financial \& Quantitative Analysis, 1, 1-35. https://doi.org/10.2307/2329989
Ross, S.A. (1977). The Determination of Financial Structure: The IncentiveSignalling Approach, Bell Journal of Economics, 8, 23-40. https://doi.org/10.2307/3003485

Sayilgan, Karabocak \& Kucukkocaoglu (2006).The firm specific determinants of corporate capital structure : Evidence from Turkish panel data, Investment Management and Financial Innovations, Volume 3, Issue 3.

Sithy Safeena, M.G.H. (2014). Impact of capital structure on profitability: A study of listed manufacturing scompanies in the Colombo stock exchange (CSE) in Sri Lanka. Journal of Management, 10(1), 60-68.

Sithy Safeena, M.G.H. (2015). Factors determining capital structure: an analysis of listed companies in the Colombo stock exchange in Sri Lanka, 5th International Symposium, 25-28.

.Su Dongwei, \& Zeng Haijian. (2009).Changes in macroeconomic factors and capital structure, Economic Research, 12. 52-65

Tharmalingam, P. \& Banda, W.Y.K.(2016).The determinants of capital structure: Evidence from selected listed companies in Srilanka, International Journal of Economics and Finance; Vol. 8, No. 2; 2016, ISSN 1916-971X.

Titman, S. \& Wessels, R. (1988). The Determinants of Capital Structure Choice, Journal of Finance, 43, 1-19. https://doi.org/10.1111/j.15406261.1988.tb02585.x

Voulgaris ,F. Asteriou,D. \& G. Agiomirgianakis, D. (2004). Size and Determinants of Capital Structure in the Greek Manufacturing Sector, International Review of Applied Economics, Taylor \& Francis Journals, vol. 18(2), pages 247-262.

Zhang, Z., Zhu, S. \& Wu, J. (2000). Factors Affecting the Capital Structure of Listed Companies, Journal of Systems Management, 9, 106-112. 
